\title{
Postmodernism as an Approach to Policy Studies - An Overview
}

\author{
Edmore Ntini, (Lecturer) \\ School of Social sciences, Department of Community Development \\ University of KwaZuluNatal, Howard College, Durban, 4041 \\ Email: eddiemza@gmail.com
}

\section{Doi:10.5901/mjss.2014.v5n8p648}

\begin{abstract}
This article analyses the possible use of postmodernism in policy studies. Too often there is confusion in the interpretation of the terms pre-modernity, modernity, modernism, modernization and postmodernism. The writer analyses these terms and illustrates their interrelatedness. Of interest is the discussion on the merits and limitations of modernism. Postmodernism is described in detail with a focus on its advantages and disadvantages as an approach to policy studies and its way forward as an approach to policy studies.
\end{abstract}

Keywords: pre-modernism, modernity, modernism, modernization, postmodernism, policy studies.

\section{Introduction}

Too often ambiguity runs through our daily use of the terms pre-modernity, modernity, modernism, modernization and postmodernism. Clearly the terms may be understood as eras, - isms and processes. In line with modern trends, it sounds reasonable to apply postmodernism in policy studies. The rigidity and biases inherent in pre-modernity and modernism should be shelved in favour of postmodernism which is currently in harmony with democratic approaches in economic, social and political spheres of our current times. Postmodernism should not be viewed as an end in itself but just as one of the -isms in the continuum of human philosophies and strategies of grappling with their times.

\section{Modernism/Modernity/Modernization}

\subsection{Premodernism}

Pre-modernism, modernity, modernism, and modernization are similar words but with quite distinctive meanings. Crouse, (2013) says Premodernism was the Christian era beginning shortly after the New Testament was written and a period characterised by orthodoxy, creeds, dogmatism and tradition with no clear line of demarcation between the material and spiritual worlds. Gail, (1997) remarks that Premodernism approved of religion or the church representing the ultimate authority and was considered the guardian of divine authority in that faith offered a higher truth and was the "interpreter of revealed knowledge".(Hoffman,2008).

\subsection{Modernity}

Modernity describes a particular social condition with social, political, cultural and economic components. Akuul, (2010) points out that modernity are a cultural conditions characterised by constant changes in the pursuit of progress. Klages, (2005) views modernity as referring to a set of philosophical, political, and aesthetical ideas which provides the basis for the aesthetics aspect of modernism. She further argues that it is fundamentally about, order, rationality and rationalization, creating order out of chaos. In this case modernity assumes that the creation of rationality leads to more order and that the more there is order in society, the better society will function. Turner, (1990) summarizes the origins and evolution of modernity convincingly: It arose with the spread of Western imperialism in the sixteenth century; the dominance of capitalism in Northern Europe in the early seventeen century; the acceptance of scientific procedures with the publication of the works of Francis Bacon, Newton and Harvey; Calvinism in the dominant classes of Northern Europe, the separation of the household and the economy, the creation of the institution of motherhood in the nineteenth century. One can note from Turner (1990) views above that modernity rests upon Enlightment beliefs that nature be 
transformed as a source social progress achieved by the systematic development of scientific and technological understanding, and by its rational application to social and economic life. Harvey, (1989) argues that modernity amounted to an extraordinary intellectual effort on the part of Enlightment thinkers to develop objective science, universal morality and law and autonomous art according to their inner logic; the scientific domination of nature for them promised scarcity, and arbitrariness of natural calamity, the development of national forms of social organization and national modes of thought promised liberation from irrationalities of myth, religion and superstition. It is safer however to view modernity along Klages (2005) line of argument that "modernity" is older than "modernism", the label "modern" emerged in nineteenth - century sociology to distinguish the present era from the previous one they labeled "antiquity". Thus in this vein, modernity refers to a set of philosophical, political, and ethical ideas which provide the basis for the aesthetic aspect of modernism.

\subsection{Modernization/Modernism}

Modernization is an economic and political process of development and change. Turner (1990) views modernization as a process by which the social world comes under the domination of ascetism, secularization, the universalistic claims of instrumental rationality, the differentiation of the various sphere of the life world; the bureaucratization of economic, political and military practices, and the growing monetization of values. Modernism therefore refers to an intellectual, aesthetic and cultural form or the movement through which that form is expressed or brought about. In the writer's understanding modernism became the name of that ideology emerging from modernity and the modernization process with capitalism, industrialization, scientism and positivism as some of its main features that have come to be called modernist ideas. One may argue alternatively that modernism may be understood as a western perspective on society, includes rational thought, humanism, democracy, the primacy of individualism over established authority. The subtle difference between the three terms modernity, modernization and modernism have so far been clarified. Modernity is reflected in aspects of a cultural, social, political and economic nature whilst modernization is an economic, social and political process of change. Modernism is the intellectual response to these changes- an ideology comprising a host of isms such as capitalism, positivism, industrialization etc. Hoffman,(2008) says modernism roughly prevailed between 1650 to 1950s and thrived on the prevalence of two approaches of knowing and knowledge namely empiricism (knowing through the senses) which gradually evolved into scientific empiricism /modern science with the development of modernist methodology and reason or logic as epistemological approaches. Thus in modernism saw the discarding of church, politics (government and kings) as primary sources of knowledge authority. Crouse, (2013) views modernism as the humanist philosophy of the Enlightenment whose main tenets were rationalism, freedom, immanence, progress and optimism, which began in the seventeenth century and ended about roughly the fall of communism. He notes that it was optimistic about discovering universal truth that would explain all life. Attwell \& Cotterill, (2000) argues that it sought explanations in the light of scientific findings. Klages, (2005) is apt in reasoning out that modernism should be perceived as the movement from which postmodernism seems have grown or emerged from.

\section{Postmodernism}

Fowler and Fowler (1990) define Postmodernism as a movement reacting against modern tendencies especially by drawing attention to former conventions. Akuul, (2010) points out that postmodernism is controversial as many scholars, intellectuals and historians do not agree on what it is and whether it exists or not but however seem to concur that there is always more than one perspective about that each perspective represents the world view. Klages (2005) observes that postmodernism is a complicated term or set of ideas and a concept hard to define because it appears in a wide variety of disciplines and hard to locate temporally or historically and its origin seems vague. Maclean \& Macmillan, (2003) asserts that it is anti-modernism by its denunciation of modern discourses and practices, used to respond to modernism and is characterised by the ascendancy of science and reason as means for both understanding and explaining the world. Attwell \& Cotterill, (2000) concur that postmodernism perceives meaning as provisional, and knowledge as merely a function of the language used to describe it. Schram (1993) views postmodernism as a growing intellectual and cultural sensibility that is being insinuated into popular and academic thought appreciating that reality is socially constructed and discursively constructed and discursively constituted. Turner, (1991) defines postmodernism as aesthetic, cultural and intellectual phenomenon encompassing particular sets of styles, practices and cultural forms in art, literature, music, architecture, philosophy and broader intellectual discourses such as deconstruction and absence of linearity. Rosenau, (1992) succinctly summarizes postmodernism as challenging global, all- encompassing world views, be they political, religious or social.. and dismisses them all as logocentric, transcendental totalizing metanarratives that anticipate all 
questions and provide predetermined answers ... Its goal is not to formulate an alternative set of assumptions but to register the impossibility of establishing any such underpinning for knowledge but to deligitimise all mastercodes. Best \& Kellner (1991) remark that it is an -ism associated with heterogeneity, plurality, constant innovation and pragmatic construction of local rules.

These views indicate that postmodern thought mounts a front against all that claims to be unequivocal, uniform, free of contradiction and closed for example against scientific systems of thought, and interpretations and styles. Postmodernism therefore, incorporates the contrary, ambiguity, paradox, chance and arbitrariness. I have mentioned earlier on that postmodernism is a reaction against modernism. Marcus and Ducklin (1997) contend that postmodernism is a result of the inadequacies of modernity theory to account for inter alia; rapid expansion of technology and its impact upon societies in terms of jobs, pay rises; continuing inequalities within and between societies; the increase in racism; the impact of globalization with multi- national companies dominating the world economy; the dominance of capitalism and the market on a global scale. Crouse, (2005) argues that postmodernism no longer shared in the optimism of the past (modernism) that reason would provide a foundation for human progress. Hoffman (2008) stresses that it brought with it the questioning of previous approaches to knowing, disqualified the one and parochial approaches to knowing and ushered in a epistemological pluralism that accommodated premodern ways (revelation), modern ways (science and reason), intuition, relational, and spiritual. He concludes that Postmodernism therefore advocated for a less hierarchial approach in which authority sources are more diffuse.

\section{Epistemology: Natural Science (Modern Approach) versus Postmodern Approach to Policy Studies}

Natural science and modern approaches to policy knowledge generation are one and the same thing whilst postmodernism has a major influence on postmodern approaches to knowledge generation. Bozeman (1986) points out that knowledge generation in the ideal science [which influences modern approaches] is a single-minded process in which the methods, technique and approaches to investigation are problem driven: research problem and hypotheses are set; data are collected on basis of relevance to the problem; research methods and techniques are chosen on the basis of appropriateness to the research problem and according to the routinized criteria such as replicability, control, formalization, reliability and validity. Postmodern approaches particularly policy research as Bozenman (1986) argues, there is no general agreement about methods and standard scientific criteria for research design are often sacrificed by the inhibiting field setting, that may not condone experimental control. Social and political factors such as knowledge and adequate skills in interpreting and analysis, and role players need to be considered. Whilst the inanimate and animate; animals and human beings and botany are studied in the same way in science (modernism), Marcus and Ducklin (1997) argue that postmodernism argues that human behaviour is more likely to be characterized by differences (heterogeneity) than by similarities (homogeneity). Dobuzinskis (1992) points out that postmodern approaches accept that social reality is constructed and generated in the very process of its being analyzed and argued about and insist the reason itself is dependent on the very process which it is supposed to judge such as social practices, and linguistic conventions. Thus postmodern approaches are a more radical critique of the cybernetic models that characterize modern approaches and articulate a new system in which control is dispensable. The acceptance of findings is yet another contested terrain. Bozeman (1986) explains how openness and communism play a part in ideal science: He points out that the research results receive a hearing in the scientific community and evaluated on their merits; peer judgments mediated by acceptable standards of theory and research; and criteria such as testability, explanatory, predicative power, elegance and reliance to existing theory are used to determine the merits and theoretical import of the research findings. Bozeman (1986) argues that postmodern approach in policy analysis acceptance and use of findings is not determined by generally agreed upon standards. Acceptance of findings is determined by variables such as self-interest, political stakes, and subjective preferences. Thus from an epistemological bases, modern approaches differ from postmodern approaches. Whilst modern approaches stress value freedom, objectivity in methods leading to true scientific knowledge that is factually grounded, postmodern approaches question the scientificness of modern approaches that do not accommodate the contrary, other views, democracy, accepting and condoning feelings, sentiments and even emotions in determining knowledge. Durning, (1993) points out that the traditional policy analysis (influenced by modernism) has failed to improve policy decision and harmed society by: undermining democratic decision making and providing misleading advice; reducing the influence of citizens on policy decisions; interfering with democratic decision making; is prone to misuse by power elites, in oppressing and exploiting the public and being used to maintain the status quo that is unfair to the powerless; being used to overrule the desire and aspirations of ordinary people, and preserving the dominance over the rest society by power elites. Underlying all these failures/weaknesses of the traditional policy is "its epistemology framework in which the analyst is viewed as an objective, value-free scientist searching for truth" Durning (1993). These 
short comings of the modern approach to policy studies are being challenged by postmodern approaches in the same field.

\section{Postmodern Approaches to Policy Studies}

Postmodern approaches to policy studies adopt a stance against the modernist tendencies that have been dominating research since the sixties. Schram (1986); Dobuzinskis (1992); Torgerson (1986) and Durning (1993) have contributed to the writer's understanding of the postmodern approach to policy studies. In this section the writer analyses the postmodern approach to policy studies as a practice; advantages and disadvantages.

\subsection{Postmodernism as a policy practice}

There are methodical advantages in adopting a postmodern approach to policy studies, as an intellectual strategy. As an analyst in development policy studies, we need to develop effective intellectual strategies. Analysts in development policy research need to look at things another way, turning them on their heads, considering perspectives that have not yet been voiced can help us take a more critical, open and comprehensive stance towards what they are studying and how they are studying it. Basing on Crouse's, (2005) views, postmodernism would enable those engaged in policy studies to acknowledge that there is no metanarrative, no objective base for critique, no one (true) world view offers an explanation to all life s issues and that paradigms are valid only within a community and that knowledge is wholly subjective and socially constructed. Agger, (1991) points out that as a practice, examines the social world from the multiple perspectives of class, race, gender and other identifying group affiliations. Schram, (1993) points out that this approach in practice does not take identity or any situation as pre-given but as constructed in the narration, tests, discourses and related media that we rely upon for analysis and making public policy. This to us analysts in development policy implies that postmodern approaches in our practice enable us to deconstruct existing versions of social reality and giving voice to other versions which are normally neglected or suppressed because they do not fall within the parameters of generally acceptable epistemological approaches of science/positivism/modernism. Dobuzinskis (1992) argues that there are a growing number of authors believing that policy analysis is essentially a process of interpretation, argumentation and refutation in a social context. This is supported by Schram's (1993) conviction that such an approach holds out the potential for inverting the dominant policy paradigm that assumes public problems are part of pre-given reality to which public policy simply responds with such arguments being reflected it is apparent that the postmodern approach in policy studies equips both us (the students) and practitioners with skills to question the dominated world, and even question the dominant assumptions of the science dominated world, and even question post modernity from the perspectives of those who today remain without choices and democratic freedoms; from the perspective of the unemployed, the single parent family, the disenfranchised minorities, ethnic minorities, and majorities both within western societies and Third World countries. Another main feature of this practice is its respect for political influences which modernism/science/positivism reject. Torgerson (1986) points out that postmodern approaches used in policy studies accommodate the broader context of social and political forces allows for the of participatory methodologies orientation, and reflect a commitment to promote a policy process permitting and encouraging greater citizen participation. This therefore shows how postmodern approaches used in policy studies honour inter alia human dignity and variations and ambiguity in the way different people view situations thus recognizing the political setting. The writer understands then that this approach in policy studies stands as a demand that the irregularity be accepted as well. Bozeman (1986) writes on the part played by social forces in problem choice; in dislodging the objectivity required for the true science as sponsors, in house- researchers, stakeholders and the would be beneficiaries carry with them their diverse values, interests, preferences seeking to influence the definition of the policy problem and approach to the problem. Bozeman (1986) concludes that added to compound and complicate the influential attempts of individuals are generalized social trends, and ideological conditions affecting the definitions and choice of policy analysis problem. Torgerson (1986) concurs that [ideologically] or political life does not yield its significance to terse hypothesis but is elusive making context supremely important, for actions and events occur in no other setting. Indeed as a student with flair for policy issues, the writer finds this practice quite relevant today in that real and practical variables such as political, cultural, racial, psychological, gender, and economic biases are accommodated as they play a significant role in shaping today's policy decisions. The Zimbabwean experience on the land issue is an apt example to refer to here. The Zimbabwe Land Policy today is influenced and determined along political lines (Mr. Mugabe desperately wants to appease the electorate so as to retain power); racism (the black Zimbabwean should replace whites in all economic circles in Zimbabwe). Xenophobia (foreigners should live Zimbabweans in charge of their heritage); Historical lines (that Zimbabweans per se have not finished their chimurenga 
(war of liberation) against Britain and her allies. Economic lines (that for long Zimbabweans blacks have been condemned to sterile soils leading to poor agricultural produce thus keeping them out of the stream economy) and Gender lines (that women should get land in their own right like men). The list of biases in the Zimbabwean Land Policy today which the writer can give is endless, may it suffice to say the postmodern approaches to policy studies seeks to ensure that we understand and accept the diversity of influences on policy processes. Crouse, (2013) maintains that postmodern approaches would ensure the repression of the past is righted. In illustrating this argument, nations such as RSA would handle policy issues with cognizance of the need to reverse the injustice of Apartheid concomitantly acknowledging that we should be a society of inclusion, tolerance and multi-cultural. Thus Torgerson (1986:49) points out that rather than being removed from the human world and turned into a neutral observer as a positivist, the post positivists researcher is returned to this world as an active participant in research Dobuzinskis (1992) argues that postmodern approach to policy studies enables researchers to take into account and appreciate the contingent and immanent of the organization they are concerned with, current policies and programmes, the relative political weight of competing interest, the expectations of their hierarchical superiors and elected officials and in the process discount information they cannot reconcile with their understanding of what is relevant to the problem at hand. This also enables postmodern researchers in contesting prevailing structures by interrogating how they "allocate value and privilege some identities on the basis of invidious distinctions" (Schram 1993). Dobuzinskis (1992) is critical of postmodern policy researchers working in institutional contexts. Such contexts limit their ability to take a critical look at their own contributions in isolation from what other actors in the system do; furthermore, they do not exercise control over the uses to which their research are put. Torgerson (1986) argues that the changing orientation in the philosophy, of the social science has implications for both policy studies and the conduct of political life; there is an understanding that the theory and practice of policy analysis are rooted in inherently political choices and decisions on modes of inquiry affect life and values of a society whilst influencing the shape of the wider political process. In such a case there is a danger of accruing political biased data. Dobuzinskis (1992) says that there is the danger of falling into a fallacy of "misplaced concreteness" if researchers do not use a variety of complementary approaches; and by further repeated comparisons among alternative models guard oneself against the illusion that one's preferred methodological option is not only adequate than others but is actually an accurate representation of reality itself. The use of complementary approaches will give us truth from various angles/perspectives, thus postmodernism "seeks to high light the practices involved in the constructing of representations of truth". Schram (1993).

In this section, we have analysed what exactly happens in the use of postmodern approaches in policy studies. Just like any approach in studying social reality, postmodern approaches in policy studies have their strengths as well as weakness. These are the aspects that the next section focuses on.

\subsection{The advantages of postmodern approaches to policy studies}

Agger (1991) explains that postmodernism suites policy studies in that by nature it is anti-reductionist and pluralist, both in its causal priorities and in its politics, which are more liberal than radical and prefers decentered knowledge available from both bureaucrats and the ordinary people engaged with the world in the irreducible perspectives of their own experience. Another advantage he notes here is the seemingly democratic nature that rejects the possibility of presuppositionless representation, instead arguing that every knowledge is contextualized by its historical and cultural nature and prefer particular modes of knowledge defined by multiplicity of people`s subject positions. Schram (1993) points out that postmodern analysis has the potential to make a distinctive democratizing contribution to policy. The advantage of using the postmodern approaches to policy studies here is that policy processes seize to be parochial as the contrary; other views/perspectives continue to be considered throughout. The postmodern approach is appreciated today because our societies are becoming increasingly presented with an increasing number of differing groups (plurality) and a tendency towards individualism as opposed to collectivism on the part of most citizens. One may argue that we thus begin to understand fragmentary subjectivities rather than coherent identities in shaping social policy. In line with such advantages is that it is possible by use of postmodern approach to understand, power relationships in our nations as contingent and pluralistic. As an analyst in development policy I am tempted to think social policies are currently generalized thus not specific enough to respect the several voices of ethnic groups. The democratic element in postmodern approach to policy issues will suite today's RSA as a good substitute for Apartheid grounded public policy. Zimbabwe's Robert Mugabe Land Policy is a war against racial and cultural pluralism in Zimbabwe. Other examples one may cite are how postmodern approaches in policy matters may influence National Social-political and economic policies in the USA in which even the First people/ Native Americans should be 'heard': the Aborigines of Australia and the Maoris of New Zealand are allowed full participation in policy processes. My argument here is that the postmodern approach to 
policy studies enables the successful breaking down of any society's existing boundaries between dominant (high) and low culture by ensuring it continues to apply the true spirit of democracy in national policy issues. As an analyst in the field of development policy, I note that postmodern approaches have the advantage of ensuring that we recognize the significance of cultural representations for understanding influences and responses to policy themes. Another advantage in using postmodern approaches lies in what Riley (1987) calls "careful calibrations". This entails that debates over subjectivity in postmodern approaches increase our subjectivity to the theorization of subjectivity and subjection. Whilst postmodern approaches in policy matters allow for the uncoupling and disrupting of the prevailing array of discourse through which subject identities are formed, there is the advantage or replacing them with new collective subjectivities. One of the major advantages one may observe from the use of postmodern approaches in policy studies is that we acquire skills in producing policy that is integrated and interdisciplinary by use of universal skills such as critical thinking. Generally we may be able to attain sound policies by use of different methods. If postmodern approaches are used, there are better chances of involving women in national policy matters. The fact that this approach question and rejects truth claims and scientific authority of an intellectual world that has been dominated by men, feminists and those sympathetic to the cause of women find a platform for the silenced gender. Torgerson (1986) points out another advantage of this approach in that it has the potential for a relationship in which politics and knowledge are no longer deadly antagonistic. These arguments advanced so far point towards postmodern approaches as including participatory approaches in policy issues. Durning (1993) states that participatory policy analysis as a postmodern approach rejects positivism, views phenomenology, or a variation of it as a better way to interpret the nature of knowledge, and accept an interpretative or hermeneutic paradigm of inquiry and can be used for initiating a participatory democracy- providing analytical inputs through PPA for interpretation and stakeholders analysis. In the following subsections, the writer will focus mainly on the advantages of the participatory method in policy analysis as an example of the postmodern approach to policy matters. Durning (1993) defines participatory democracy as a political system in which each citizen is able to authentically engage in the political process of policy decision making. Durning (1993) advances the following advantages: It improves society by helping to redistribute power: It is a critical and empowering method that challenges traditional policy analysis leading to elite domination of politics by allowing for active participation by the citizenry in policy process not managed by the elite; it stresses debate and reasoning about issues of public interest and activities in political matters of the communities; it produces analysts capable of providing critical contributions to policy discourse challenging established and entrenched ways of thinking; It prepares citizens for enhanced roles in policy making and this would decrease the power of the people and groups that exert the most influence on political making, by means of vast resources. Torgerson (1986) although commenting on the Berger Inquiry (1974), Canada reveals some of the advantages of this approach such as that it encourages the participation of non-experts particularly the affected; experience that promotes individual and collective reasoning and effective participation; and the creation of an open forum for deliberations on public issues. Torgerson (1986) and Durning, (1993) indicate that there are other methodological merits such as the use of open discussions, speech and argumentation leading to a developed capacity to recognize and articulate interests by the citizens. Durning, (1993) points out that policy analysts in this case assume a new role, that of helping citizens formulate and express their arguments, facilitating dialogue and empowerment; ensuring theoretical and empirical knowledge relate to the participants' (citizens') circumstances and providing participation with a wide base on which to take courses of action they feel are suitable for them. When it comes to analytical inputs, "citizens and others likely to be affected by policy decisions have the opportunity to provide information and opinion inputs at public fora such as public hearings" (Durning 1993). Durning (1993) makes it clear that analysts take into account the contributions of the expanded range of actors in making decisions, and sound recommendations. Durning, (1993) argues that another advantage of this is that the whole process of a wider base of citizen participation in policy issues with it greater access to and visibility in the halls of power on the part of people. Interpretative participatory policy analysis as Durning (1993) evaluates it has the advantage of involving both stakeholders and citizens to provide analytic inputs and involvement in production of analysis. This ensures that there is clarity of both context and reality. This section has demonstrated effectively the advantages of using postmodern approaches in policy issues.

\subsection{Disadvantages of the postmodern approaches to policy studies}

In the previous sections, I have looked at postmodern approaches to policy studies as a practice and the advantages therein. Central to both has been the element of participatory democracy with the involvement of the citizenry in all stages of policy process. This has been observed as one of the differences between this approach and that of positivism. There are several disadvantages in using postmodern approaches in policy studies. Castillo, (1983) points out that participation [which is central in postmodern approach] is time consuming, often nerve - wrecking and can become a Pandora's box of 
problems; communities that should be involved [the citizenry] tend to be concerned with their own interests [making policy matters trivial]; In conceptualizing involvement, the perceptions are often limited to the involvement of men (seldom women); and people's participation poses problems to authorities sensitive to public protest. Other disadvantages are that the postmodern approach may not be acceptable in all countries as the person of the state head determines a lot. According to the UNDESA (1975) popular participation reduces a leader's ability to make decisions unilaterally because many operational decisions are then decentralized and more people involved in discussions; privileged elite groups having a monopoly in decision making experience a loss of power. This is typical in some Third World countries whose leaders tended/tend to centralize instead of decentralizing power. It appears we have a long way to go before Africa for example addresses democracy in such crucial and sensitive areas like policy making. In the writer's experience as a development analyst, there has been observation on situations when debates on national issues have been shunned in Zimbabwe; opposition parties, individuals and NGOs who seek to engage the government in national policy debates run the risk of being labeled a subversive elements being sued by the ZANU PF's illusionary enemies. Reference is made of illusionary enemies in the sense that Robert Mugabe's government exaggerates its fears of the West to gain support of the people. The people in some developing countries leave every policy matter to the politicians. UNDESA (1975) points out that this is not because people recognize any special virtue in their political leadership, but because they desire to be relieved of the anxieties and responsibilities imposed by participation in decision making. Another problem is that participation in policy by citizenry may be hard hit by apathy as people have other things to. UNDESA (1975) point out that active participation requires time to attend meetings, vote and inform oneself about issues. This is often acceptable to a great number of citizens, particularly in societies where privatization of life has gone far and additional demands for civic participation can only be met by foregoing personal activities. Whilst postmodernism may have the above limitations, it is however worthy noting policy issues should be handled expertly to avoid what Crouse, (2005) calls "victimization" in areas of race and racism, nationalism (one nation lording over another), religion and religious bigotry, sexism (to them male and female are not the only genders) and specieism (discrimination of one species over another). Some areas I find postmodernism needing to be clear in policy studies in the area of policy in conquest states versus negotiated states. There is need for policy analysts to study closely the dilemma created by approaches to policy issues in conquest states. I propose to define conquest states as those states that came to existence by force or attained independence by armed rebellion. In such states policy is imposed and room for negotiation is unheard of. In such states the leadership proceeds with a sense of vengeance, no negotiations, with force and policy issues confined to a few members. Policy is meant to redress the injustice of the past regimes at all cost. One may wonder how postmodernism may find its place in such undemocratic policy arena. Postmodernism could not have worked in Mobutu`s Zaire, Amin`s and Obote 's Uganda as well as Samora Machel's Mozambique. Negotiated states are those that I propose to regard as ones that came into existence by round table conferences/settlements opposed to the conquest states where war was a deciding factor. Policy studies would need to take note that at times the dictates of those settlements determine policy. Such cases as the land policy in Zimbabwe that was influenced by the Lanchester House Constitution of 1979 did not make logic at as it did not do justice to the core cause of the war namely land ownership and the resultant political and socio-economic injustice. Land policy in this regard allowed a minority to keep owning the land whilst the majority remained disadvantaged for decades after uhuru. My argument here is that policy process cannot be fair and even equal in these types of states. Postmodernism identifies the bias, allows for democratic debates on issues that otherwise may not have been tabled for brainstorming and cannot deal with matters of equality and fair play critical to contesting parties.

International/superpower/industrialized states policies versus developing states policies is another sphere where postmodernism may be applied vigorously. Postmodernism enables policy analysts to articulate the biases and disadvantages experienced by developing countries as a result of policies emanating from the industrialized nations. Socio-economic policies of and from the West have been known to create misery and poverty in Third world nations. The pathetic situation today is that Third World nations still look to the West for both support and approval of their policies mainly for WB/IMF funding and UN support. To me, postmodernism needs to be effectively used to charter new relations between nations. If policy fails to bring equally between nations of the world then we are having a soap bubble that vanishes on the tough of reasonable inquiry. I agree with Akuul (2010) that in these times of globalization the benefits of African states have become questionable as they have lost their sovereignty. They have lost control of their policy making and implementation which is now under the World Trade Organisation in which they are not represented unlike in the WB, IMF, WHO and UN where the representation is either a token one or of no significance. I have no doubt that postmodernism as a policy approach has " not helped in the pathetic situation that Africa's interests are not considered and brought to bear on policies that concerns issues of international economic relations" (Akuul 2010). Postmodernism seems to fail to address policy dynamics that emerge and result from the following as perceived by Akuul (2010) capital flight, labour migration and travels, cross border trade, the weakening of safety nets for low-skilled workers, brain drain, 
poverty, the unequal global economic system and the unfair global economic agenda that has prevailed since colonialism. One may wonder whether the economic agenda of the West in Third World countries and in Africa in particular has shifted towards equality and fair play. Postmodernist policy analysts need to expose those current and subtle international policy gimmicks that perpetuate global economic inequality.

Another area I find interesting for postmodernism in policy studies is matters of criticism versus debate that have become a buzz word in the media today. Criticism and debate yield policy and are products of policy. When opposition parties, policy analysts/critics, and parliamentarians criticize policy they are generating more and sharper policies. Debate on policy issues exposes the limitations and strengths of policy on one hand whilst on the other hand it may be viewed as constructive and destructive. I do not see the criticism-debate and constructive criticism-destructive criticism as manifestations of contradictions in policy issues. Contesting views in society generate policy views that postmodernism would interrogate and may accept unlike modernism would have done. Whilst ruling parties and their adherents boast of positive criticism, accuse their opponents of destructive criticism and the opposition parties screaming foul and accuse their opponents of being partisan, one may notice that more content for policy analysis is being generated. Parliamentary governments make the best policies for their citizens by way of wider participation of the citizens in policy issues, allowing broader space for criticism. The availability press releases of political parties, organisations with an interest in national policy matters, political party manifestos for study by other parties and national and international conferences allow for possibility of sharper policies. I argue them that postmodernism is the ideal isms currently that may be use concomitantly with democracy on policy studies.

\section{Conclusion}

The real science method (positivism/modernism) do not sound adequate for the social sciences because they do not take into account the history, contexts, the feelings, sentiments, ideology, opinion and beliefs of the subjects being investigated. Postmodern approaches sound adequate today because we are embracing democracy and appreciate that social sciences are people-centered disciplines. In deciding what affects people we need a multi-perspective approach particularly in policy issues. The postmodern approach to policy studies today is thwarted by hostile political leadership making it unsafe for use particularly in Sub-Sahara Africa. Policy processes are still a preserve of the elite and one would recommend that this monopoly be broken. The way forward for the postmodern approach to policy issues perhaps lies in improving participation in all levels of political parties so that participatory democracy grows with party members. Another proposal is that local government structures could be involved in ensuring that people get to be used to being involved in matters that affect them in smaller way. Governments should not be too suspicious of NGOs as these can teach by practice how people can be involved in matters that affect them from village to national level.

\section{References}

Agger, B.(1991). Critical theory, poststructuralism, postmodernism: Their sociological relevance. Annual Review Sociology, 17: 105-131. Akuul, T. (2010). Postmodernism and its relevance to African development. Continental Journal of sustainable development 1: $57-61$. Attwell, C.A.M. and Cotterill, F.P.D. (2000). Postmodernism and African conservation science. Biodiversity and conservation 9: p 559 - 577. Bozenman, B. (1986). The credibility of policy analysis: Between method and use. Policy Studies Journal 14(3), March: 519-538 Castillo, G.T. (1983). How Participatory is Participatory Development? A review of the Philippine experience. Manila. PIDS.

Crouse, B. (2013). Postmodernism: A new paradigm. C.I.M. outline\#58. www.rapidresponsereport.com/briefingpaper /postmodernism58.pdf Accessed 30/12/13.

Dobuzinskis, L. (1992). Modernist and Postmodernist metaphors of the policy process: Control and stability versus class and reflexive understanding. Policy science_25:355-380.

Durning, D. (1993). Participatory study policy in a social services agency: a case. Journal for Policy Analysis and Management 12(2): $297-322$.

Fowler, H.W. and Fowler, F.G. (1990). The Concise Oxford Dictionary Of Current English. $5^{\text {th }}$ edition. Oxford. Claredon Press.

Gail, W. (1997). A postmodern approach to structured dependency theory. Journal of Social Policy, 26 (3) pp342 - 350.

Harvey, D. (1989). The Conditions of postmodernism. Cambridge. Polity Press.

Hoffman, L. (2008.The three major philosophical epochs. www.postmodernpsychology.com/philosophical-systems/overview.htm Accessed $30 / 12 / 2013$

Klages, M. (2005). Postmodernism. www.willmette.edu/ rloftus/postmod.htm Accessed 30/12/2013.

Marcus, M and Ducklin, A. (1997). Sociology. London. John Murray Publishers.

Riley, D.(1987). Does sex have a history? Women and Feminism. New Foundations 1 Spring.

Rosenau, P.M. (1992). Post- modernism and the Social Sciences. Princeton University Press. Princeton.

Schram, S.F. (1993). Postmodern policy analysis: discourse and identity in Welfare policy. Policy Sciences 26:249-270.

Torgerson, D. (1986). Between knowledge and politics. Three faces of policy analysis. Policy Sciences 19:3-59.

Turner, B.S. (1991). Theories of Modernity and Postmodernity. London. Sage.

United Nations Department of Economic and Social Affairs. 1975. Popular_Participation in Decision-making. New York. United Nations. 